Blonna D. Terrible triad of the elbow. Issue Rehabil. Orthop. Neurophysiol. Sport Promot 2018; 23:53-61. DOI: 10.19271/IRONS-00063-2018-23

\section{TERRIBLE TRIAD OF THE ELBOW}

Davide Blonna

Department of Orthopedic and Traumatology, Mauriziano “Umberto I” Hospital, University of Turin Medical School, Torino, Italy

\section{SUMMARY}

The terrible triad of the elbow consists of a posterior dislocation of the elbow, characterized by fractures of the radial head and the coronoid process. It was called "terrible" due to the high chance of poor outcomes observed in past with both conservative and surgical treatment. A high percentage of complications has been reported in the literature, including residual instability, stiffness, heterotopic ossification (HO) and arthritis.

The aim of this manuscript is to review the most key features of this complex disease and to propose a flow chart that could help the reader to choose the better treatment to achieve satisfactory results in most of the patients.

Keywords: posterior elbow's dislocation, treatment algorithm

Date received: 5th January 2018

Date accepted: 10th February 2018

\section{Introduction}

Under the name of terrible triad of the elbow are grouped elbow's conditions of differ severity but always characterized by three elements: 1) elbow dislocation, 2) fractures of the radial head and 3) fracture of the coronoid process (Figure 1). This condition accounted for $4 \%$ of adult radial head fractures and $31 \%$ of elbow dislocations. It is called "terrible" because of the high probability of complications,

\section{NIESZCZĘŚLIWA TRIADA ŁOKCI}

Davide Blonna

Department of Orthopedic and Traumatology, Mauriziano “Umberto I” Hospital, University of Turin Medical School, Torino, Włochy

\section{STRESZCZENIE}

Nieszczęśliwa triada łokcia polega na tylnym zwichnięciu stawu ramienno- łokciowego, charakteryzującego się złamaniem głowy kości promieniowej i wyrostka dziobiastego. Została nazwana nieszczęśliwą z powodu dużego ryzyka złego wyniku leczenia zaobserwowanego w przeszłości, zarówno po leczeniu zachowawczym jak i operacyjnym. W literaturze odnotowano wysoki odsetek powikłań, w tym niestabilność, sztywność, skostnienie heterotopowe (HO) i zmiany zwyrodnieniowe.

Celem tej pracy jest dokonanie przeglądu najbardziej kluczowych cech tego złożonego urazu i zaproponowanie schematu postępowania. Algorytm za zadanie pomóc w wyborze najlepszego leczenia w celu uzyskania satysfakcjonujących wyników u większości pacjentów.

Słowa kluczowe: tylne zwichnięcie łokcia, algorytm leczenia, nieszczęśliwa triada łokcia

Data otrzymania: 5 stycznia 2017

Data zaakceptowania: 10 luty 2018

including instability, stiffness, $\mathrm{HO}$ and arthritis.

\section{Aim}

The aim of this paper is to review the most key features of this complex disease and to propose a flow chart that could help the reader to choose the better treatment to achieve satisfactory results in most of the patients. 


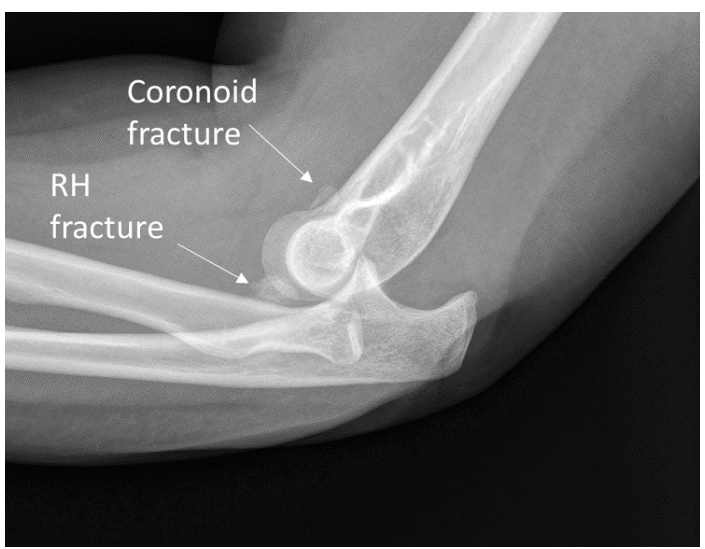

Figure 1. Lateral view of the elbow showing a dislocation of the elbow, a radial head $(\mathrm{RH})$ fracture and a coronoid fracture.

\section{Anatomical Tips And Pathogenesis}

Elbow dislocation is not common since the stability of the elbow is guaranties by several factors. Anatomic elements that contribute to the stability of the elbow can be divided in primary and secondary stabilizers, which interact to guarantee a stable elbow through the entire range of motion. Primary stabilizers are the coronoid, the medial collateral ligaments, and the lateral collateral ligament complex. The secondary stabilizers are the radial head, the common flexor-pronator tendons, the common extensor tendons, and the capsule. If one of the primary stabilizers is deficient, as the coronoid, due to trauma, the secondary stabilizers become imperative stabilizers. In a terrible triad pattern of fracture-dislocation most of the primary and secondary stabilizers of the elbows are fractured or torn. The severity of the disruption of the primary and secondary stabilizers of the elbow explains the different degree of instability that can follow a terrible triad pattern of injury.

Not all the terrible triads are the same in terms or residual instability. After the reduction a terrible triad, the elbow can be stable or grossly unstable depending on extend of radial head and coronoid fracture and the severity of the soft tissue damage. The variability of residual instability justifies the large variety of possible treatments. Possible treatments can range from conservative treatment to multiple aggressive surgeries.

\section{Pathogenesis}

The traumatic mechanism that causes a terrible triad injury is similar to the injury that causes a posterolateral dislocation of the elbow (O'Driscoll, 1999). It consists in a fall onto a slightly flexed elbow and pronated forearm as the hand initially hit the ground. Then, the humerus internally rotates with respect to the fixed forearm (relative supination of forearm) and a valgus and compression force affects the elbow. If the energy of the trauma is low and/or the trauma occurs in full or almost full extension, the trauma can affect just soft structures (simple dislocation of the elbow). Instead, a high energy trauma and/or a trauma in flexion with a significant compression and valgus force, can affect also the bony stabilizers of the elbow, leading to a terrible triad pattern of injury.

\section{Clinical Evaluation}

Patients locally have pain, swelling and limited range of motion of the elbow. The anatomical profile of the elbow is usually not preserved similarly to a posterolateral dislocation of the elbow. Usually, patients can identify the episode of dislocation. It is important to perform a neurovascular examination, before and after the reduction maneuver, mostly for the ulnar nerve due the valgus force.

The reduction maneuver consists in applying pressure, doing a traction in a semi-extended position, from the posterior to the anterior part of the olecranon tip. In some cases, it can be necessary pronation-supination and flexion of the arm to disengage the radial head form the back of the capitulum humeri. In case of terrible triad, the reduction maneuver usually does not require a significant force, since the presence of a radial head end coronoid fracture makes the reduction maneuver easier. A complete avulsion of the common extensor tendon 
justifies an even easier reduction. The reduction can be performed with or without anesthesia, but it is preferable doing it under anesthesia. This allows the physician to assess carefully the residual instability of the elbow.

When the elbow is reduced the physician progressively brings the elbow from full flexion to full extension measuring at which angle the elbow dislocates or subluxes. The principle is that the elbow is intrinsically more stable in flexion and pronation and less stable in extension and supination. If the elbow dislocates or subluxes in a more flexed position it means that is grossly unstable. On the contrary, if the residual instability occurs only in full or almost full extension and only if a forse in external rotation of the forearm is applied by the examiner, it means that the residual instability is marginal, and a conservative treatment can be considered (Blonna, 2015).

\section{Diagnosis}

Standard radiographs of the elbow are required before and after reduction. Although conventional radiographs obtained can be satisfactory, computed tomography scans (CT) is mandatory if a terrible triad pattern of fracture-dislocation is suspected. The CT allows the surgeon to better foreseen to degree of residual instability and decide the proper treatment for that specific type of terrible triad. The CT scan is mandatory to a complete assessment the amount of coronoid and radial head fracture.

\section{Coronoid Fracture}

The coronoid is a primary stabilizer of the elbow. The classification of Reagan-Morrey is the most used and it classified coronoid fractures in three groups, considering the dimension of the fragment assessed in the lateral view of a standard $\mathrm{x}$-ray and CT scan (sagittal bone window) (Regan and Morrey, 1989). Type I coronoid fracture involves just the coronoid apex. Type II coronoid fracture involves approximately $50 \%$ of the coronoid heights. Type III coronoid fracture consists in more than $50 \%$ of the coronoid heights.

The degree of coronoid involvement, according to Reagan-Morrey classification, is one -but not the only- of the element that the physician must consider in order to suggest conservative or surgical treatment. A type I fracture can be considered generally a good prognostic factor while a type III a negative prognostic factor. However, one of the most common errors that the physician can do, is to consider only the type or coronoid fracture in the decision-making process. A type I coronoid fracture, in a terrible triad pattern of injury, can require an aggressive surgical treatment in case of concomitant severe damage of the other stabilizers of the elbow occurs.

\section{Radial Head Fracture}

In normal condition radial head is a secondary stabilizer of the elbow, but in terrible triad it becomes a primary stabilizer, due to the insufficiency of the primary stabilizers.

Radial head fractures are generally classified according to Mason's classification. In case of a terrible triad, the radial head fracture is classified always as type IV (fracture of the radial head plus elbow dislocation). For this reason, the Mason's classification is not very useful for decision making process. Nevertheless, the amount of radial head involvement mast be taken into great consideration in the decision-making process. In our experience, a replacement rather than a fixation is suggested for 3-part radial head fracture, or for more comminuted fracture. It is important to note that a "simple" fracture of the anterior part of the radial head should not be underestimated, since it is the anterior part of the radial head that constraints against posterolateral instability.

\section{Soft Tissue Injury}

All the soft tissue structures (lateral collateral ligament, medial collateral ligaments, anterior capsule, medial and lateral common tendon unit), are important for the 


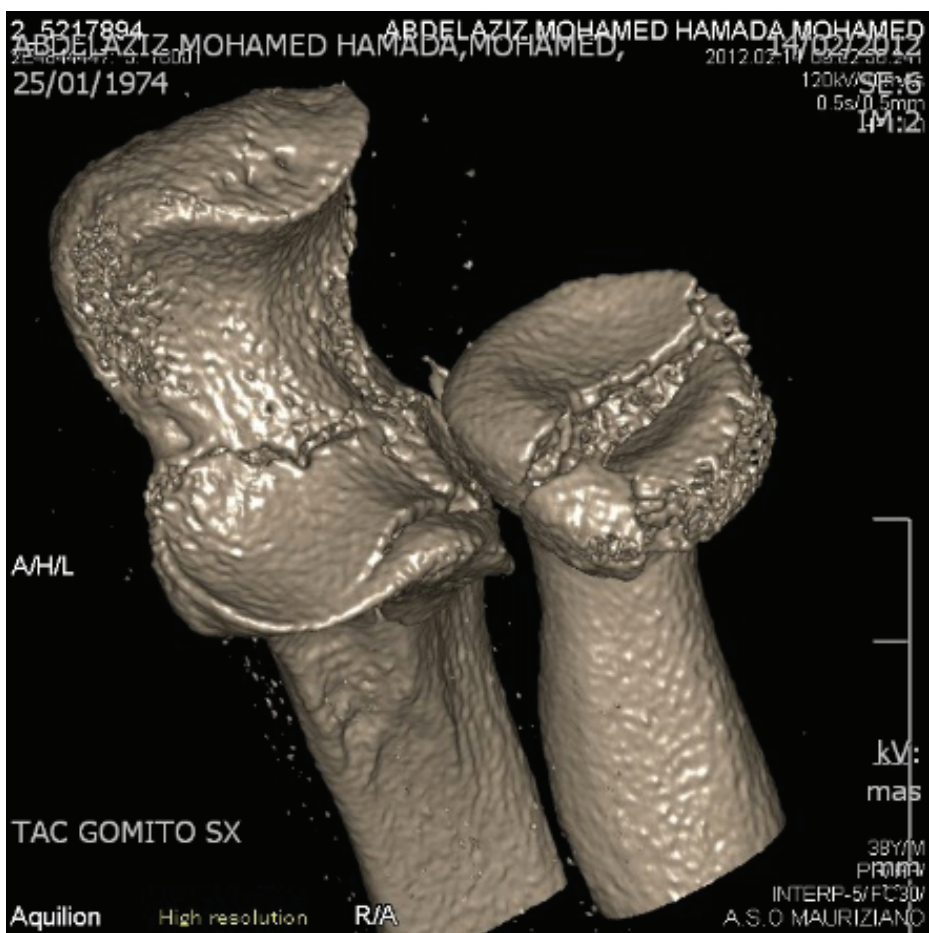

Figure 2. The CT scan shows an involvement of the tip of the coronoid and a comminution of the anterior part of the radial head. In this case a radial head replacement was indicated.

stability of the elbow. In most terrible triads, these structures are partially or completely injured. The amount of the soft tissue involvement in the terrible triad pattern of injury explains partially or entirely the residual instability of the elbow. However, the type and severity of soft tissue involvement is difficult to assess in a terrible triad. The assessment of the contribution of the single soft tissue stabilizers of the elbow to the residual instability is not accurate even in expert hands.

For this reason, an examination of the overall residual instability is suggested under anesthesia. This examination provides indirect information of the soft tissue involvement. For example, an elbow unstable in flexion and pronation strongly suggest a complete tear of the LCL complex (including common tendon unit), capsule and MCL. A minor instability that occurs only in extension and supination is more commonly seen with an isolate lesion of the LCL and anterior capsule. A grossly unstable elbow but with a minor bone involvement, can be justified by a concomitant severe damage of the MCL, LCL, capsule median and lateral common tendon units.

\section{Treatment}

There are many different options to treat terrible triad of the elbow (Sørensen and Søjbjerg 2011; Bohn et al. 2014; Fitzgibbons et al.2014; Blonna 2015; Sanchez-Sotelo and Morrey 2016). Conservative treatment and surgery can be both valid and giving good functional results.

\section{Conservative treatment}

The conservative treatment consists in immobilizing the elbow at approximately 90 of flexion in pronation for 3 to 4 weeks. Usually, this treatment is reserved to patient with low compliance, many comorbidity and low functional requests. Conservative treatment can be also chosen for patients with a Type I coronoid fracture and a minor residual instability (subluxation that occurs only in full or almost full extension and supination). If conservative treatment is the treatment 


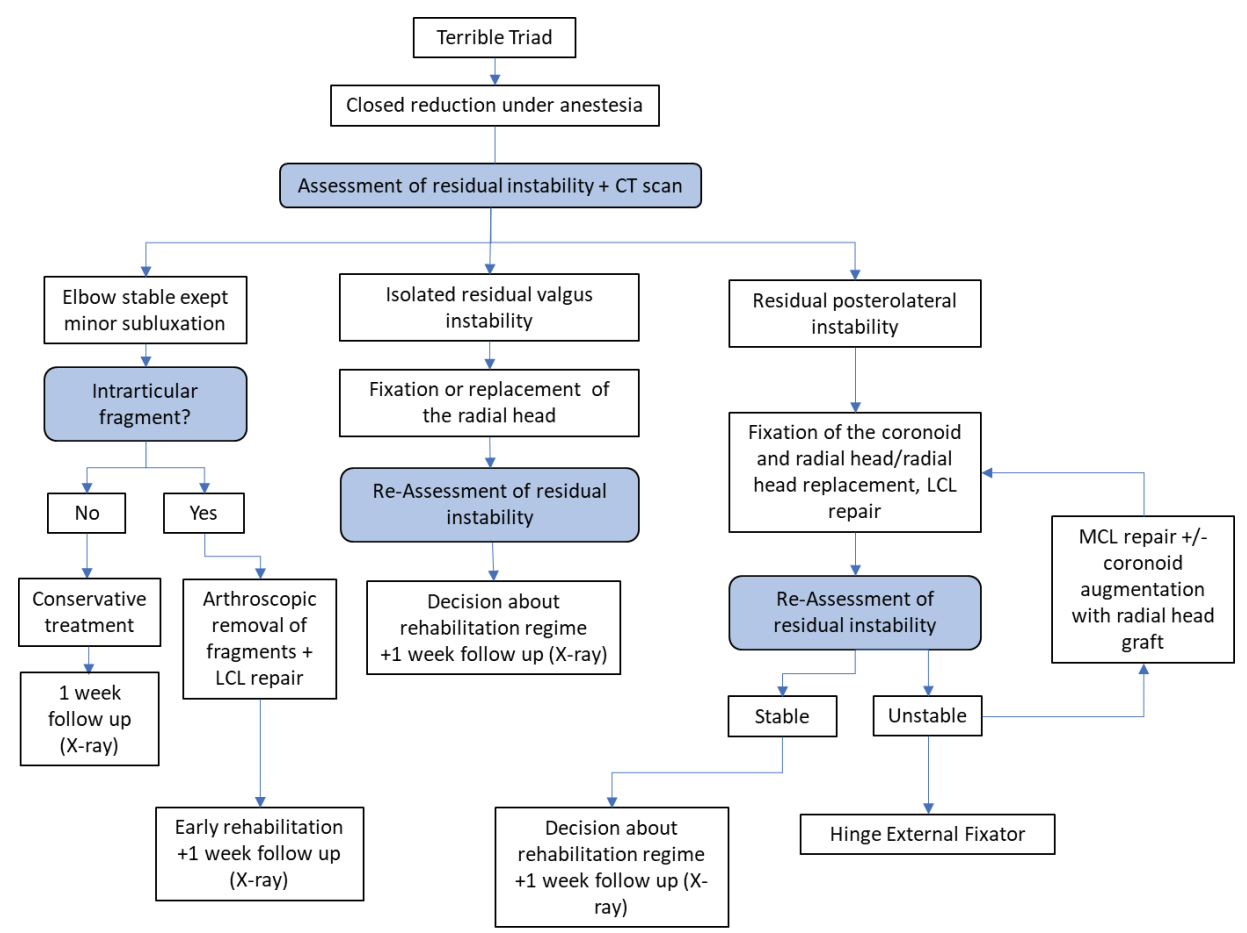

Figure 3. The flowchart shows our prefer treatment for terrible triad patter of injury according to residual instability.

of choice, a close follow up is mandatory. I suggest a standard X-ray, 7 days after trauma, to detect any signs of static instability.

\section{Surgical treatment}

Most of terrible triad injuries require surgical treatment. The type of surgical treatment and exposures depends on several factors and can range from arthroscopic fixation to more aggressive surgeries.

Most of the terrible triads can be successfully treated by a single lateral approach. The lateral approach can be either a classic Kocker approach or a more soft-tissue sparing Kaplan approach (Kaplan, 1941). Using the lateral approach, the radial head fracture and the LCL tear can easily be addressed. The coronoid fracture can also be successfully fixed by using the lateral approach. The fixation of the coronoid from the lateral approach is easier in case of extensive fracture of the radial head since the remnant of the radial head does not obstruct the surgeon. To improve the view of the coronoid from the lateral approach a proximal extension of the skin exposure is generally suggested. From the lateral approach a retrograde fixation of the coronoid is usually recommended.

If any doubt remains regarding the stability of the coronoid fixation a medial approach is recommended by a Hotchkiss over-the-top approach or using the flexor carpi ulnaris splitting approach.

A single posterior skin approach or a double lateral plus medial skin approach is required in all the cases of severe comminution of the coronoid. In these cases, the fixation of the coronoid required a direct visualization, reduction and fixation by using multiple screws of anatomical plates. When we plan to fix the coronoid by a medial approach we prefer a double skin approach rather than a single posterior approach. In our experience the double skin approach reduces complication related to large skin flaps, typically seen after single posterior skin approach.

\section{Lateral collateral ligament repair}

The lateral collateral ligament must be repaired, as it is a primary stabilizer. Considering the dynamic of the trauma, it is often avulsed off from the lateral epicondyle and 
it has to be reattached to restore the stability as much close to the normal stability as possible. LCL can be repair using suture anchors or transosseous sutures. We normally use a $5 \mathrm{~mm}$ double-loaded metallic anchor, placed 1 to $2 \mathrm{~mm}$ anterior to the lateral epicondyle. With one mattress suture the LCL is embraced to the lateral common tendon unit and with the second mattress suture the LCL is embrace to the annular ligament (Blonna, 2015).

\section{Postoperative management}

After surgical treatment the stability is evaluated. If the elbow is stable through the entire range of motion, the patient is placed

\section{Results}

Different studies demonstrated that results in the early treatment groups are better than those in patients undergoing late reconstruction, in terms of clinical scores and range of motion (Wang et al. 2014). In their systematic review, Chen et al. (2014) reported that functional outcomes, as determined by assessing Mayo elbow performance, Broberg-Murray, and/or DASH scores were consistently satisfactory. Indeed, with regards to Mayo elbow performance and Broberg-Murray scores, approximately $70 \%$ or more of patients had good to excellent scores. Further, less than $10 \%$ of patients had poor scores (Chen and Ring, 2015).

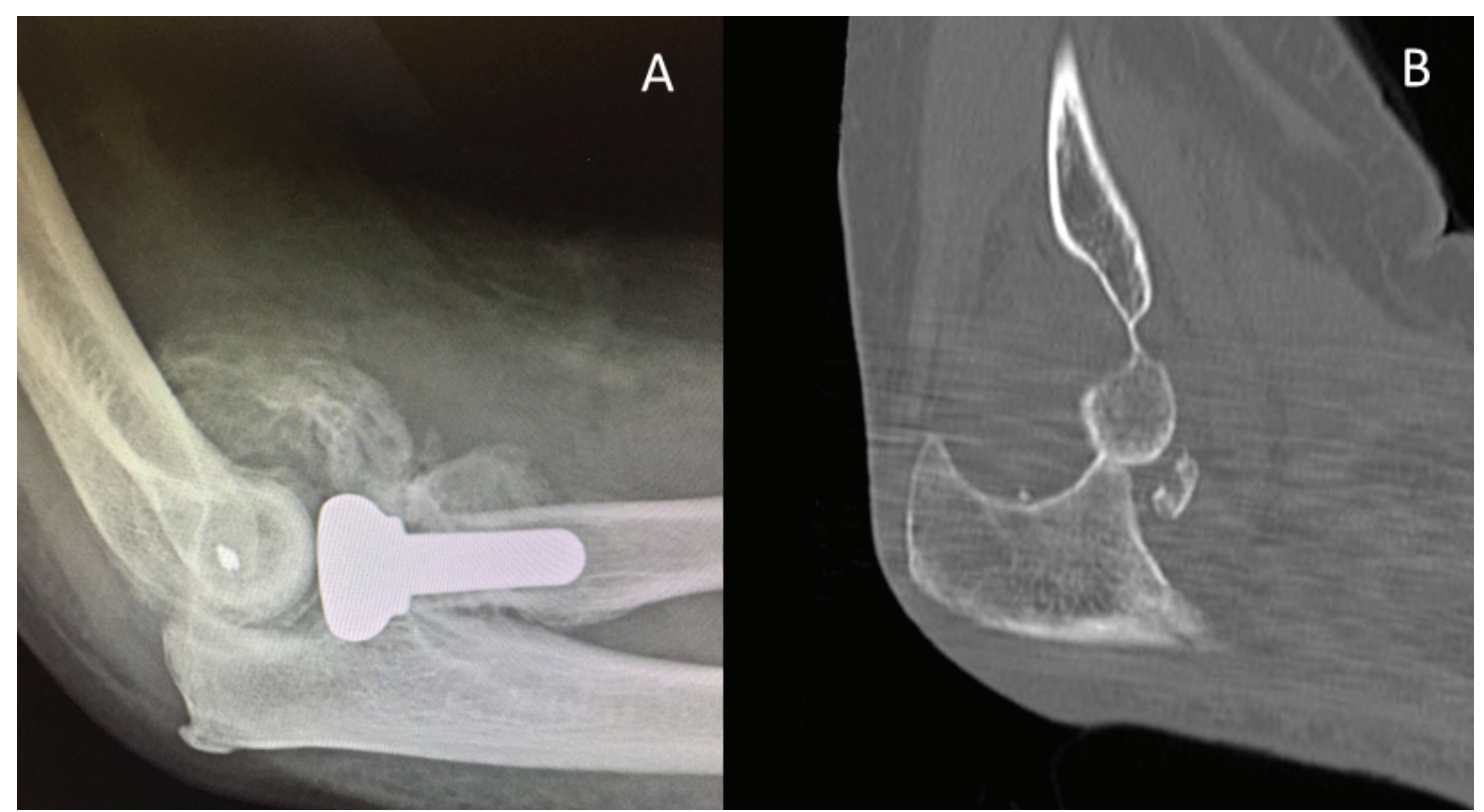

Figure 4. (A) Extensive heterotopic ossification after surgical treatment for a terrible triad. (B) Recurrent dislocation 30 days after conservative treatment for a terrible triad of the elbow.

in an elastic bandage and a full active and passive range of motion is allowed immediately after surgery. The patients are however instructed not to stress the elbow in full extension. A more prudent post-op regime is recommended in case of residual instability. If a significant residual instability is diagnosed after surgery an external fixator is recommended especially in case of difficulties encountered during coronoid fixation.

\section{Discussion and conclusions}

Complications

Unfortunately, terrible triad of the elbow is strictly linked to a high number of complications, both in conservative and surgical treatment. Most common complications are residual instability, stiffness, heterotopic ossifications (Figure 4 A, B), pain, ulnar neuropathy and osteoarthritis. Chen et al. (2014) reported that 5 of 11 (45.4\%) patients experienced redislocation (Chen and Ring, 2015); Forthman et al. (2207) reported that 4 of 22 
(18.2\%) patients experienced ulnar neuropathy and that 3 of $22(13.6 \%)$ patients experienced joint stiffness. Chen et al. (2014) reported that the most common complications that did not require reoperation were heterotopic ossification (12.5\% patients) and arthrosis (11.2\% patients). Re-operation is necessary in as many as $28 \%$ of patients (Chen et al. 2014).

Conclusions

The terrible triad is still considered one of the worst scenarios that afflicts the elbow, due to potential poor outcomes. Focusing on anatomy and pathogenesis is the key to find the proper treatment. Despite good results have been achieved so far, more studies and researches are required. 
REFERENCES

Blonna, D. (2015) 'Terrible Triad'. In: Castoldi F., Blonna D., Assom M. (eds) Simple and Complex Fractures of the Humerus. Springer, Milano, pp. 327-337.

Bohn, K., Ipaktchi, K., Livermore, M., Cao, J., Banegas, R. (2014) 'Current treatment concepts for 'terrible triad' injuries of the elbow'. Orthopedics. Dec;37(12), pp. 831-837. Chen, HW., Liu, GD., Wu, LJ. (2014) 'Complications of Treating Terrible Triad Injury of the Elbow: A Systematic Review'. PLoS ONE 9(5): e97476.

Chen, N.C., Ring, D. (2015) 'Terrible Triad Injuries of the Elbow' J Hand Surg Am. 40(11), pp. 2297-2303.

Fitzgibbons, PG., Louie, D., Dyer, GS., Blazar, P., Earp, B. (2014) 'Functional outcomes after fixation of 'terrible triad' elbow fracture dislocations' Orthopedics., 37(4), pp. 373-376.

Forthman, C., Henket, M., Ring, DC. (2007) 'Elbow dislocation with intra-articular fracture: the results of operative treatment without repair of the medial collateral ligament' J Hand Surg Am., 2007 Oct;32(8), pp. 1200-1209. Kaplan, EB. (1941) Surgical approaches to the proximal end of the radius and its use in fractures of the head and neck of the radius. J Bone Joint Surg., 23, p. 86.

O'Driscoll, SW. (1999). Elbow instability. Acta Orthop Belg. 65(4), pp. 404-415.

Regan, W., Morrey, B. (1989) 'Fractures of the coronoid process of the ulna'. J Bone Joint Surg Am., 71, pp. 1348-1354.

Sanchez-Sotelo, J., Morrey, M. (2016) 'Complexelbow instability'. EFORT Open Rev., pp. 183-190.

Sørensen, AK., Søjbjerg, JO. (2011) 'Treatment of persistent instability after posterior fracture-dislocation of the elbow: restoring stability and mobility by internal fixation and hinged external fixation'. J Shoulder Elbow Surg., 20 (8), pp. 1300-1309.

Wang, W., Liu, J., Liu, S., Ruan, H., Li, X.; Fan, C. (2014) 'Arthrolysis combined with reconstruction for treatment of terrible triad injury with a poor outcome after surgical as well as conservative intervention'. Arch Orthop Trauma Surg., 134, pp. 325-331.

60 Issues of Rehabilitation, Orthopaedics, Neurophysiology and Sport Promotion - IRONS 
Author reported no source of funding.

Author declared no conflict of interest. Author responsible for correspondence Davide Blonna

Department of Orthopedic and Traumatology University of Turin Medical School Largo Turati 60, 10128, Torino, Italy Email:davide.blonna@gmail.com
Autor nie zgłosił źródła finansowania.

Autor nie deklarował konfliktu interesów.

Autor odpowiedzialny za korespondencję:

Davide Blonna

Department of Orthopedic and Traumatology University of Turin Medical School Largo Turati 60, 10128, Torino, Włochy davide.blonna@gmail.com 